\title{
Investigating the Determinants of Inflation: A Panel Data Analysis
}

\author{
Pinar Deniz ${ }^{1}$, Mahmut Tekçe ${ }^{1} \&$ Ahmet Yilmaz ${ }^{1}$ \\ ${ }^{1}$ Department of Economics Marmara University, Istanbul, Turkey \\ Correspondence: Pinar Deniz, Department of Economics, Marmara University, Goztepe Campus, 34722, Istanbul, \\ Turkey.
}

Received: March 27, 2016

Accepted: April 12, $2016 \quad$ Online Published: April 18, 2016

doi:10.5430/ijfr.v7n2p233

URL: http://dx.doi.org/10.5430/ijfr.v7n2p233

\begin{abstract}
Maintaining price stability is the main objective of central banks all over the world. Each central bank requires a unique monetary policy rule as the characteristics and structure of each economy is idiosyncratic. Economic diversities necessitate special efforts, however, theories emerged from former experiences worldwide led to generalizations of some monetary policies neglecting the differences between industrialized and emerging economies. This paper studies how inflation rates of inflation targeting (IT) and non-inflation targeting (non-IT) emerging and industrial economies are affected with the determinants as money growth, real effective exchange rate, budget balance, GDP growth, real wages and output gap using static and dynamic panel data analysis for the period 2002-2012. Decomposing the determinants of inflation rate enables to investigate the existence of several transmission mechanisms for emerging and industrial economies.
\end{abstract}

Keywords: inflation targeting, emerging countries, panel data

\section{Introduction}

Achieving price stability is the most common statement of central banks all over the world. Each bank, inherently, requires a unique monetary policy rule since the domestic and foreign economic conditions are idiosyncratic. Economic diversities necessitate special efforts of policy-makers. However, theories emerged from former experiences worldwide led to generalizations of some monetary policies by many central banks neglecting the special economic conditions of the relevant country. Pegging exchange rate, monetary targeting, inflation targeting are some of the generalized monetary policy regimes that have been tested by economies. Nevertheless, many emerging markets, together with the substantial changes in monetary policies, succeeded in reducing inflation figures especially after 2001 (Note 1). In this study, relatively lower global inflation period is examined and the determinants of inflation are investigated taking into account of the differences between industrial and emerging market economies.

The well-known monetarist argument that links inflation to money supply by Friedman (1956) is the most popular approach that is proved in many studies (Komulainen and Pirttila, 2002; Grauwe and Polan, 2005). However, there are many other mechanisms scrutinized in the literature. Besides money supply growth rate, some key variables, i.e., exchange rate (real effective), GDP growth rate, output gap, budget balance and real wage are investigated as the determinants of consumer price inflation.

Real exchange rate is generally defined as the relative price of goods across countries which implies competitiveness of traded goods among these countries. Through Balassa-Samuelson effect, which argues that economic growth is related to productivity in traded goods, real exchange rate depends on the marginal productivity of labor, i.e., real wage, in tradable goods. A rise in productivity growth in the traded goods has a positive impact on the price of nontraded goods and further on domestic inflation (Égert et al., 2003). The transmission mechanism from exchange rate on inflation is also examined in the studies on exchange rate pass-through. Exchange rate pass-through is historically one of the reasons for high inflation. Mihaljek and Klau (2008) argue that even if inflation is fairly stable and the pass-through has declined in recent years via rise in global and domestic competition, pass-through is still high in countries with historically high inflation. One extreme case is pricing to market which implies no pass-through due to the fixed import price that is more likely to occur in industrial countries. The other extreme situation is when imported goods are sold in domestic market at the current exchange rate. This one is, rather, observed in historically high inflation countries. 
Budget deficit is mainly one of the concerns of the economic policy making. It is argued that governments may turn out to have large and persistent fiscal deficits, which may need to be financed by money creation, i.e., seigniorage, rather than selling new government bonds, if fiscal policy dominates monetary policy. In this case, monetary authority is forced to issue money which will further lead to rise in the rate of inflation (Sargent and Wallace, 1981). Phillips curve literature suggests a positive correlation between output growth and inflation, whereas quantity theory equation postulates a negative correlation. Output gap, based on new Keynesian Phillips curve is argued to contribute to inflation, together with expected inflation. Real wage is frequently used as a measure of competitiveness under the argument that real wage is equal to marginal productivity of labor.

The empirical work in this study is based on panel data analysis in order to examine the differences between group characteristics of inflation targeting (IT) and non-inflation targeting (non-IT) emerging economies (EMEs) and industrialized economies. Our results are closely consistent with the empirical finding in the relevant literature. Empirical findings in this study generally reflect diverse results for different country groups. At this point, it becomes crucial to identify monetary policies taking into account of countries' own characteristics (idiosyncratic structure) rather than following a specific monetary policy.

The paper is organized as follows. Section 2 discusses the studies that examine the relationship between inflation and several macroeconomic variables and the literature on inflation targeting policy. Section 3 summarizes the data and descriptive statistics and illustrates the inflation figures of IT emerging and industrialized economies. Section 4 explains the model and the empirical findings and the last section concludes the paper.

\section{Literature Review}

Inflation targeting (Note 2) has become a popular monetary policy regime with the pioneer of New Zealand in 1990. One of the reasons why targeting monetary aggregate via controlling money growth rate was not successful is the instability of money demand. Dynamic inconsistency problem frequently occurred when monetary authority mistakenly followed short term goals rather than focusing on long term objectives. Inflation targeting avoids this problem by preventing monetary authority to change their policy since the objective of the policy makers is apparent and easy to follow by the individuals.

There are many studies that advocate the benefits of IT regime. In order to examine whether IT is beneficial, studies mainly concentrate on the impact of inflation targeting on main macroeconomic variables such as growth rate and inflation rate. Mishkin and Schmidt-Hebbel (2007) argue that IT reduces inflation in advanced countries. Johnson (2002) observes that IT advanced economies experience a decline in expected inflation. Levin et al. (2004) show that IT helps to reduce persistence in inflation with emerging markets more successfully compared industrialized economies. However, they are sceptical about the reason for the decline in inflation asserting that it may be attributed to the global downward trend in inflation rate. Svensson (1997) argues that a stable decline in inflation variability will render output less variable. Neumann and von Hagen (2002) assert that IT enables convergence by contributing lagging economies to catch up with leading economies.

On the other hand, opponents of inflation targeting claim that decline in inflation rate is achieved at the expense of other economic aims. Cecchetti and Ehrmann (1999) argue that IT increases variability in output. Lin and Ye (2007) examining the effect of IT in seven industrialized economies state that IT has no significant impact on inflation and variability in inflation. Ball and Sheridan (2005) also find no empirical evidence to claim that IT improves economic performance observing the sample for IT and non-IT developed economies with moderate inflation rates. Likewise, Brito and Bystedt (2010) conclude that there is no significant evidence that IT improves economic performance for emerging economies. Inflation reflects a poor decline but IT leads to a decline in growth rate which can be interpreted as evidence that IT does not contribute to economic performance.

Ball (1999) and Leitemo et al. (2002) argue that lagged change in the real exchange rate affects inflation through import prices. Kamin (1997) utilizing annual data for the period between 1970-1996 observed that the responsiveness of inflation to the real exchange rate is higher in Latin America than in Asian or industrialized countries. Likewise, Svensson (2000) and Çağlayan et al. (2012) argue that real exchange rate has a direct positive effect on consumer price inflation where real exchange rate is defined as the ratio of foreign prices in local currency by domestic prices (Note 3). Klau (1998), focusing on 22 Sub-Saharan countries' dataset, argue that appreciated real effective exchange rate leads to a decline in the rate of inflation. Moreover, it is observed that the coefficient is higher in the CFA (Communauté Financière Africaine (Note 4)) franc countries compared to non-CFA countries.

Karras (1994) examining the relationship for 32 countries, using panel estimation and does not find any inflationary impact of fiscal deficits. Likewise, King and Plosser (1985) do not observe a significant link from fiscal deficit to 
inflation using time series analysis for 13 countries. Conversely, Fischer et al. (2002), employing panel fixed effects for 94 developing and developed economies, observe that fiscal deficits are the main drivers of high inflation. Catao and Terrones (2005) and Lin and Chu (2013), differently from the literature, model a non-linear relation between fiscal deficit and inflation. Utilizing a dynamic panel analysis for 107 countries within the period 1960-2001, they observe a strong positive relationship for high-inflation developing countries, whereas the relationship is insignificant for advanced countries.

Durevall (2012) examining the quarterly dataset for Brazil within the period 1968-1985 argues that money growth and oil price lead to a rise in inflation whereas output growth decreases the rate of inflation. Masso and Staehr (2005) examine the existence of Phillips curve, which reflects the link from output gap and inflationary expectations on current rate of inflation, for the three Baltic countries, controlling for several other indicators, such as real effective exchange rate, unemployment rate, oil price and industrial production. The results differ by the country selection but industrial output and exchange rate movements reflect significant impact on inflation. Lim and Papi (1997), focusing on Turkish economy for the period 1970-1995, observe that money, exchange rate and fiscal deficits have significant and strong impact on the rate of inflation, whereas wages do not reflect substantial impact on inflation.

\section{Data}

The sample is composed of 34 OECD and 6 non-OECD member economies (Brazil, China, India, Indonesia, Russia and South Africa). 17 out of 40 economies are emerging economies and the rest are industrialized. The 11 IT emerging economies are Brazil, Chile, Czech Republic, Hungary, Indonesia, Israel, South Korea, Mexico, Poland, South Africa and Turkey. Non-IT economies are China, Estonia, Greece, India, Russia and Slovenia. The 7 IT industrialized economies are Australia, Canada, Iceland, New Zealand, Norway, Sweden and the UK. Non-IT industrialized economies are Austria, Belgium, Denmark, Finland, France, Germany, Ireland, Italy, Japan, Luxembourg, Netherland, Portugal, Slovak Republic, Spain, Switzerland and the US. The main databases utilized are OECD, World Development Indicators (WDI) and Bank for International Settlements (BIS). Datasets not available in these databases are obtained from domestic statistical agencies of each country and adjusted according to the other dataset. CPI inflation data are obtained from OECD. Inflation is the percentage change on the same period of the previous year. Money growth rate (Note 5) (the annual change in money and quasi money, referred as monetary aggregate of M2) are obtained from WDI. GDP growth rate and output gap are calculated using GDP (constant prices at US currency with base year 2005) from WDI. Budget balance (Note 6) (general government) as a ratio of GDP data are from OECD. Real effective exchange rate indices (Note 7) (CPI-based, broad indices and average) are from BIS. Annual real minimum wages (Note 8) (in US dollar) are from OECD. Output gap is calculated via HP filter after taking natural logarithm of GDP data. BB/GDP refers to budget balance as a ratio of GDP. REER represent real effective exchange rate. A rise in REER implies appreciation. Annual dataset is used throughout the paper.

Table 1. Inflation targeting adoption dates

\begin{tabular}{|c|c|c|c|}
\hline \multicolumn{2}{|c|}{ Industrialized Countries } & \multicolumn{2}{|c|}{ Emerging Markets } \\
\hline Country & rgeting adoption & Country & $\begin{array}{c}\text { Inflation targeting } \\
\text { adoption }\end{array}$ \\
\hline Australia & 1993 & Brazil & 1999 \\
\hline Canada & 1991 & Chile & 1999 \\
\hline Iceland & 2001 & Czech Republic & 1997 \\
\hline New Zealand & 1990 & Hungary & 2001 \\
\hline Norway & 2001 & Indonesia & 2005 \\
\hline Sweden & 1993 & Israel & 1997 \\
\hline \multirow[t]{5}{*}{ UK } & 1992 & Korea, Republic of & 2001 \\
\hline & & Mexico & 2001 \\
\hline & & Poland & 1998 \\
\hline & & South Africa & 2000 \\
\hline & & Turkey & 2006 \\
\hline
\end{tabular}

Source: Jahan (2012)

Note: Finland, the Slovak Republic, and Spain adopted IT but abandoned it after the adoption of Euro. 

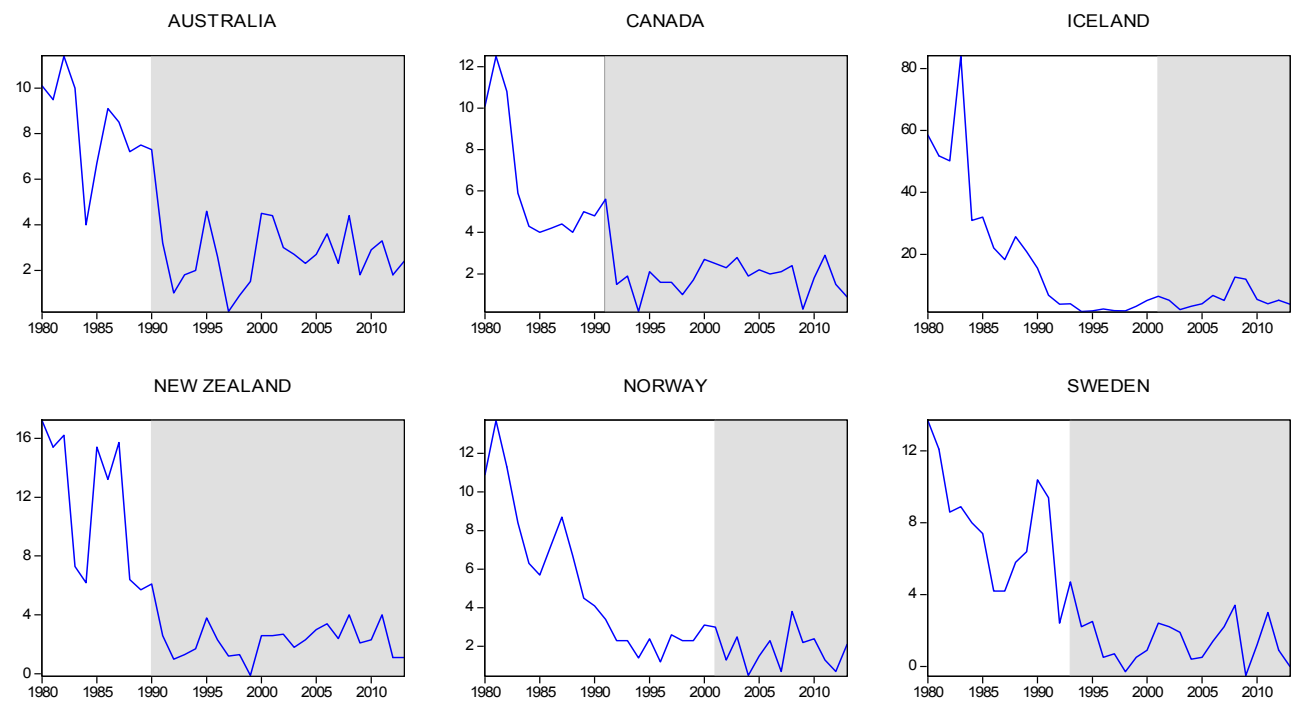

UK

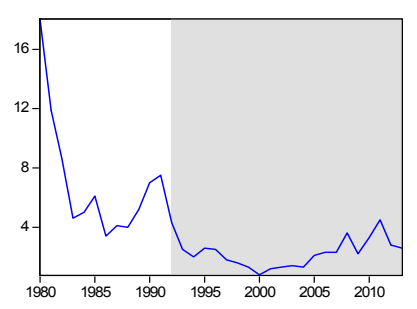

Graph 1. Industrialized countries - Inflation after inflation targeting regime Note: Shaded area depicts the IT period.
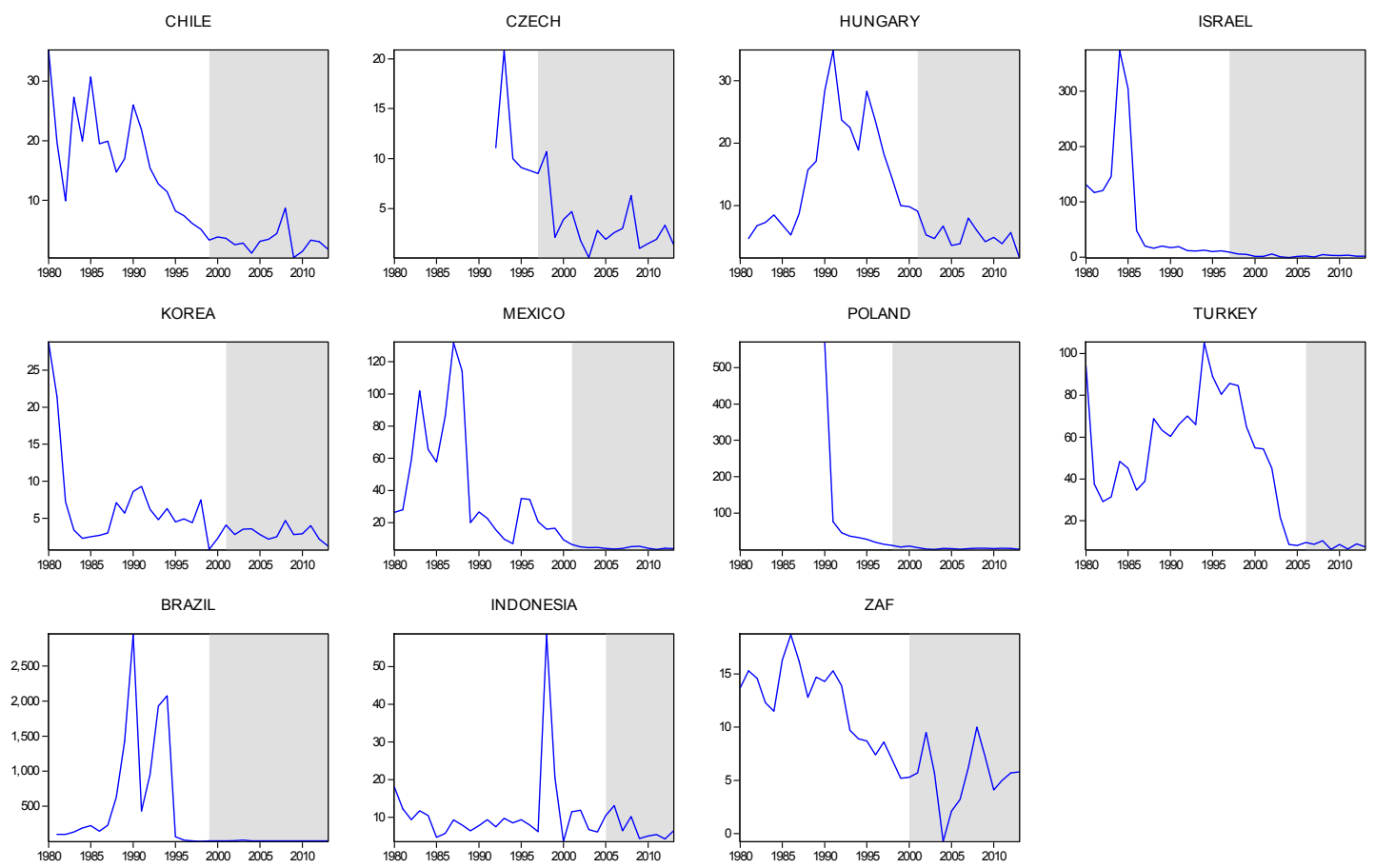

Graph 2. Emerging market countries - Inflation after inflation targeting regime 
Table 2. Descriptive statistics for emerging and industrialized economies

\begin{tabular}{lcccc}
\hline Variable & IT EMEs & Non-IT EMEs & \multicolumn{1}{c}{ IT Indus } & Non-IT Indus \\
\hline Inflation (\%) & 5.49 & 5.18 & 2.77 & 2.09 \\
& $(6.38)$ & $(3.75)$ & $(2.01)$ & $(1.53)$ \\
Output gap & -0.003 & 0.005 & 0.001 & 0.001 \\
& $(0.026)$ & $(0.048)$ & $(0.025)$ & $(0.024)$ \\
GDP growth (\%) & 3.54 & 4.81 & 2.14 & 1.48 \\
& $(2.84)$ & $(5.50)$ & $(2.42)$ & $(2.65)$ \\
BB/GDP (\%) & -1.90 & -2.08 & 0.72 & -2.74 \\
& $(3.60)$ & $(4.72)$ & $(6.56)$ & $(4.28)$ \\
Money growth (\%) & 12.32 & 15.92 & 9.84 & 6.31 \\
& $(11.79)$ & $(15.99)$ & $(10.56)$ & $(7.74)$ \\
REER & 93.07 & 94.93 & 101.42 & 98.64 \\
& $(13.10)$ & $(8.34)$ & $(15.86)$ & $(7.77)$ \\
Wage & 5798.52 & 6907.85 & 19192.48 & 16432.74 \\
& $(3364.69)$ & $(3813.36)$ & $(5218.84)$ & $(7634.73)$ \\
Obs. & $132 / 96$ & $66 / 44$ & $84 / 48$ & $192 / 120$ \\
\hline
\end{tabular}

Note: "Indus" refers to industrialized countries. Values above are averages and values in parenthesis are standard deviations. Observations (Obs.) distinguish the total sample size and the sample size after removing countries with wage data unavailable with "/", successively.

\section{Model and Empirical Results}

\subsection{Methodology}

The models examined for inflation rate are given below:

$$
\begin{gathered}
\pi_{i, t}=\left(\beta \cdot \pi_{i, t-1}\right)+\alpha+\delta \cdot x_{i, t}+\varepsilon_{i}+e_{t}+v_{i, t} \\
\pi_{i, t}=\left(\beta \cdot \pi_{i, t-1}\right)+\eta+\vartheta \cdot x_{i, t}+\mu \cdot I T_{i, t}+\varepsilon_{i}+e_{t}+v_{i, t}
\end{gathered}
$$

where $\pi_{i, t}$ is CPI inflation rate, $\pi_{i, t-1}$ is the lagged value of inflation rate, $x_{i, t}$ is a vector of variables that affect inflation rate and the subscript $i=1,2, \ldots N$ refers to the cross sectional unit, i.e., country, $t=1,2, \ldots N$ refers to the time period. The term $\varepsilon_{i}$ allows for cross sectional fixed effects, $e_{t}$ allows for time effects that common to all cross sectional units and $v_{i, t}$ is the disturbance term. Fixed effect model captures the unobserved country-specific and/or period-specific heterogeneity within the panel dataset and eliminates the heterogeneity from the model. Vector $x_{i, t}$ refers to any variable that can have an effect on inflation. In this study, real effective exchange rate, real minimum wage, output gap, GDP growth, money growth and budget balance as a ratio of GDP are employed as the several determinants of inflation. Regression (1) examines the impact of relevant variables on current inflation considering the conditions including lagged inflation, and regression (2) investigates overall data (distinction of emerging and industrialized countries) examining the impact of IT via dummy variable. $I T_{i, t}$ is equal to 1 if the country is implementing inflation targeting regime in period $t$, and 0 otherwise. Lagged value of inflation as a regressor in (1) controls for the normal dynamic of inflation. In a standard New Keynesian Phillips curve, inflation is indicated as a function of expected inflation and output gap:

$$
\pi_{t}=\beta \pi_{t+1}^{e}+\lambda \tilde{y}_{t}
$$

In that case, it is of static form and unable to capture the persistence of inflation (inertia). Benati (2008) states that there are advocates and proponents of building inflation persistence in macroeconomic models. One of the most popular attempt to build inflation persistence into the structure of macroeconomic models is done by Christiano et al (2005) under the argument that firms which are unable to re-optimize prices will change it taking into account of past inflation. The proponents argue that there is not sufficient evidence to universally adopt inflation persistence into macro models. Moreover, such back-ward looking indexation of prices is questioned to be structural in the sense of 
Lucas (1976). Hence, there is no consensus on the literature for the inclusion of inflation persistence. This study shows both dynamic and static panel data results.

Inclusion of lagged dependent variable in fixed or random effect models is criticized to be erroneous since it will result in correlation between error term and lagged dependent variable. This correlation problem is referred as endogeneity. The lagged value of the dependent variable, i.e., $\pi_{i, t-1}$, captures the inertia in inflation and turns the model from static to a dynamic form. At this point, Arellano and Bond (1991) dynamic panel GMM technique is suggested to estimate the dynamic model. The technique is based on first differencing the estimating equation (hence, this technique is referred as difference GMM) in order to capture the unobserved heterogeneity (fixed effect), and employing the lagged values of the regressors in level form as instrumental variables. Inclusion of instrumental variables eliminates the endogeneity problem, however, weak correlation between current differences of the explanatory variables and the lagged values of the instrumental variables in levels creates an estimation problem in the difference GMM technique. Arellano and Bover (1995) propose system GMM technique alternative technique to overcome this issue. Roodman (2006, p.104) explains system GMM as "instead of subtracting the previous observation from the contemporaneous one, it subtracts the average of all future available observations of a variable". Both techniques, i.e., difference GMM and system GMM, are designed for a panel data with small period and large cross section unit. The validity of the GMM model is also tested using Sargan statistics (Note 9), a test for over-identifying restrictions, and $\operatorname{AR}(2)$ statistics (Note 10), a test for serial correlation.

\subsection{Results}

For emerging and industrialized economies, Tables from 3 to 9 represent various results for equations (1) and (2). Table 3 presents the determinants of inflation for non-IT and IT emerging economies using fixed effects model. Tables 4 and 5 reflect the estimates when all emerging economies are examined together and the distinction is ensured via dummy variable using fixed effects and panel GMM, successively. Tables from 6 to 9 depict estimates for industrialized countries. Fixed effect (FE) panel analyses excluding lagged dependent variable give static results whereas analyses including lagged dependent variable FE model and GMM give dynamic results. GMM analysis is employed in order to avoid technical problems emerging from inclusion of lagged dependent variable in FE model. GMM is designed for panel dataset with small time period, larger cross sectional unit. Thus, GMM is employed only in the situations that are appropriate to this feature.

There may be multicollinearity problems together with the dependency among some variables such as money growth and GDP growth or real wage and REER. In order to circumvent the problem, different combinations of the variables are utilized within the regression models.

\subsubsection{Empirical Findings for Emerging Economies}

Tables 3 to 5 present that lagged inflation is significantly effective on current inflation level in EMEs. However, the inertia, i.e., coefficient for the lagged dependent variable, is relatively higher in IT EMEs, given in Table 3. Historically high inflation countries have higher inflation inertia which renders it more difficult for the monetary authority to control inflation. As observed in Table 2, IT EMEs reflect higher inflation rates on average compared to non-IT EMEs. Relatively higher inertia can be attributed to this evidence.

Real effective exchange rate is negative and highly significant in all cases. A rise in REER (Note 11) by an appreciation in the domestic currency leads to a decline in the price of imported goods leading to a decline in overall inflation. Exchange rate changes that are passed on to the domestic prices of traded goods are referred as "exchange rate pass through". Empirical findings support pass through for emerging market economies (Choudhri and Hakura, 2006; Frankel et al., 2005; Ca'Zorzi et al., 2007). There is also a literature considering real exchange rate as a measure of productivity such that a rise in productivity growth in the traded goods has a positive impact on domestic inflation through the rise in the price of nontraded goods (Égert et al., 2003). Dynamic panel GMM analyses excluding real wage also reflect negative impact from REER given in Table 5. Even though there are benefits from appreciation of the currency, overvaluation leads to loss of competitiveness in the global arena through a rise in the value domestic goods in terms of foreign goods. A persistent overvalued currency will create balance of payments problems and render the economy fragile through dependency on capital flights.

Output gap in Non-IT EMEs reflects a positive impact on inflation in static model. Dynamic panel (GMM) also suggests positive impact for overall EMEs. Budget balance reflects significant coefficients only in the overall static regressions given in Table 4. The negative impact of budget balance on inflation can be expressed by role of government. The rise in deficit has to be financed by selling bonds (open market operations). Selling bonds to central 
bank rather than public generates seignorage effect through direct money creation. Neyapti (2003) argues that budget deficit leads to inflationary effects when central bank is not independent and the financial market system is not functioning properly. GDP growth also reflects a negative impact on inflation in IT EMEs in static model and in overall EMEs using FE model. This can basically be interpreted under quantity theory of money. A rise in output growth will increase money demand which further leads to a fall in the price level, given the money supply. Moreover, for emerging markets, a decline in growth rate can be perceived as a risk for global investors leading to capital outflow from domestic economy. Outflow will depreciate domestic currency and increase price level via exchange rate pass through mechanism. Money growth reflects positive impact on inflation in dynamic and static models in overall EMEs and IT EMEs under FE model. This is also consistent with quantity theory of money such that a rise in money supply will end up in a rise in prices.

It is observed that real wage increases inflation in static analyses. Real minimum wage can both be perceived as an indicator for global competitiveness and for labor productivity. Emerging markets are simply the economies of high potential for growth, but they are generally in need of finance which is an impediment against growth. Another reason for inadequacy in finance is the risk for foreign investors carried through vulnerabilities in leading economic indicators. Hence, a rise in real wage is a disincentive for foreign investors that intent to make foreign direct investments and deteriorates both growth rate and leads to capital outflow which further leads to rise in inflation. Moreover, the EMEs have very low wages compared to industrialized economies, given in Table 2, and a rise in wages will lead to a rise in their expenditure level which further triggers the rise in inflation. The impact of IT regime on inflation is also examined to be compatible with the existing literature on inflation targeting. Dummy variable to observe the effect of IT reflects negative and significant impact on inflation in FE models, given in Table 4. However, this may be illusionary. Dummy variables in regressions (3) and (4) are insignificant where lagged value of inflation is included. Ball and Sheridan (2005) argue that omitting lagged inflation when analyzing the impact of inflation targeting will create bias on the IT coefficient. Willard (2012, p.2242), based on several studies that observe negative impact of IT on inflation for developed economies, such as Truman (2003), explains that such "results seem likely to be due to the exclusion of lagged inflation from their specification". He further states that other papers on developing economies provide more convincing findings, however, they generally do not employ instrumental variable techniques to control for a potential endogeneity problem. Hence, the impact of IT is not clear. In order to remove the problems emerging from exclusion of lagged inflation in models with IT dummy, the regression models are also examined with the division of IT and non-IT economies.

Table 3. Estimates of the determinants of inflation for non-IT and IT emerging economies

\begin{tabular}{|c|c|c|c|c|c|c|c|}
\hline Regressors: & $\frac{\text { Non-IT }}{(1)}$ & $\frac{\text { Non-IT }}{(2)}$ & $\frac{\text { Non-IT }}{\text { (3) }}$ & $\begin{array}{c}\text { Non-IT } \\
(4)\end{array}$ & $\begin{array}{l}\text { IT } \\
(5)\end{array}$ & $\begin{array}{l}\text { IT } \\
(6)\end{array}$ & $\begin{array}{l}\text { IT } \\
(7)\end{array}$ \\
\hline $\begin{array}{l}\text { Lagged } \\
\text { inflation }\end{array}$ & $\begin{array}{l}0.32 * * \\
(0.01)\end{array}$ & $\begin{array}{l}0.40 * * \\
(0.00)\end{array}$ & & & $\begin{array}{l}0.57 * * \\
(0.00)\end{array}$ & $\begin{array}{l}0.57 * * \\
(0.00)\end{array}$ & \\
\hline REER & $\begin{array}{c}-0.15 * * \\
(0.00)\end{array}$ & $\begin{array}{c}-0.14 * * \\
(0.01)\end{array}$ & $\begin{array}{c}-0.19 * * * \\
(0.00)\end{array}$ & & $\begin{array}{c}-0.06 * * \\
(0.04)\end{array}$ & $\begin{array}{c}-0.07 * * \\
(0.01)\end{array}$ & $\begin{array}{c}-0.23 * * \\
(0.00)\end{array}$ \\
\hline Output gap & $\begin{array}{c}20.13^{* * *} \\
(0.01)\end{array}$ & & $\begin{array}{c}24.10 * * \\
(0.00)\end{array}$ & & $\begin{array}{l}-8.02 \\
(0.54)\end{array}$ & & \\
\hline BB/GDP & $\begin{array}{c}0.02 \\
(0.84)\end{array}$ & $\begin{array}{l}-0.01 \\
(0.94)\end{array}$ & $\begin{array}{c}0.14 \\
(0.25)\end{array}$ & $\begin{array}{c}0.05 \\
(0.71)\end{array}$ & $\begin{array}{c}0.09 \\
(0.47)\end{array}$ & $\begin{array}{c}0.07 \\
(0.54)\end{array}$ & $\begin{array}{c}-0.75^{* *} \\
(0.00)\end{array}$ \\
\hline $\begin{array}{l}\text { GDP } \\
\text { growth }\end{array}$ & & $\begin{array}{c}0.12 \\
(0.18)\end{array}$ & & & & $\begin{array}{c}-0.34^{* *} \\
(0.02)\end{array}$ & $\begin{array}{c}-0.87 * * \\
(0.00)\end{array}$ \\
\hline$M$ growth & $\begin{array}{l}-0.01 \\
(0.45)\end{array}$ & $\begin{array}{l}-0.01 \\
(0.60)\end{array}$ & $\begin{array}{l}-0.02 \\
(0.33)\end{array}$ & $\begin{array}{l}-0.02 \\
(0.31)\end{array}$ & $\begin{array}{l}0.08^{*} \\
(0.06)\end{array}$ & $\begin{array}{l}0.12 * * \\
(0.02)\end{array}$ & $\begin{array}{l}0.09^{*} \\
(0.06)\end{array}$ \\
\hline Wage & & & & $\begin{array}{l}3.55^{*} \\
(0.08)\end{array}$ & & & $\begin{array}{l}6.72 * \\
(0.10)\end{array}$ \\
\hline Dummy & & & & & $\begin{array}{c}0.79 \\
(0.56)\end{array}$ & $\begin{array}{c}0.63 \\
(0.64)\end{array}$ & $\begin{array}{c}-7.26^{* *} \\
(0.00)\end{array}$ \\
\hline R-squared & 0.84 & 0.82 & 0.80 & 0.61 & 0.81 & 0.82 & 0.77 \\
\hline
\end{tabular}

Note: Dependent variable is inflation. P-values are given in parenthesis. Dependent variable is CPI inflation rate. Panel data includes a time period of 2002-2012 with 6 cross units for non-IT in regressions (1), (2) and (3) whereas the period is between 2001 and 2012 for 11 IT countries given in regressions (4) and (5). Regressions (4) and (7) include real wage for non-IT and IT emerging economies, successively. India and Russia are absent in non-IT and Brazil, Indonesia, South Africa are absent in IT economies in regressions (4) and (7) due to lack of real wage data. The panel regressions above have time and country effects. $(*)$ and $(* *)$ denote $10 \%$ and $5 \%$ significance level, successively. The test used is panel fixed effects. 
Table 4. Estimates of the determinants of inflation for emerging economies (Non-IT and IT together)

\begin{tabular}{|c|c|c|c|c|c|c|c|c|}
\hline Regressors: & (1) & (2) & (3) & (4) & (5) & (6) & (7) & (8) \\
\hline Lagged inflation & & & $\begin{array}{l}0.63 * * \\
(0.00)\end{array}$ & $\begin{array}{l}0.62 * * \\
(0.00)\end{array}$ & & & & \\
\hline REER & $\begin{array}{c}-0.12^{* * *} \\
(0.00)\end{array}$ & $\begin{array}{l}-0.13 * * \\
(0.00)\end{array}$ & $\begin{array}{c}-0.08 * * \\
(0.00)\end{array}$ & $\begin{array}{c}-0.09 * * \\
(0.00)\end{array}$ & $\begin{array}{c}-0.26 * * \\
(0.00)\end{array}$ & $\begin{array}{c}-0.29 * * \\
(0.00)\end{array}$ & & \\
\hline Output gap & $\begin{array}{l}-2.42 \\
(0.83)\end{array}$ & & $\begin{array}{c}0.71 \\
(0.91)\end{array}$ & & $\begin{array}{c}-31.27 * * \\
(0.01)\end{array}$ & & & $\begin{array}{c}-33.99^{* *} \\
(0.01)\end{array}$ \\
\hline BB/GDP & $\begin{array}{c}-0.49 * * \\
(0.00)\end{array}$ & $\begin{array}{l}-0.43 * * \\
(0.00)\end{array}$ & $\begin{array}{l}-0.05 \\
(0.58)\end{array}$ & $\begin{array}{l}-\mathbf{0 . 0 1} \\
(0.95)\end{array}$ & $\begin{array}{c}-0.54 * * \\
(0.00)\end{array}$ & $\begin{array}{c}-0.42 * * \\
(0.01)\end{array}$ & $\begin{array}{l}-0.56 * * \\
(0.00)\end{array}$ & $\begin{array}{c}-0.63 * * \\
(0.00)\end{array}$ \\
\hline GDP growth & & $\begin{array}{l}-0.22^{*} \\
(0.08)\end{array}$ & & $\begin{array}{c}-0.17^{* *} \\
(0.02)\end{array}$ & & $\begin{array}{c}-35.42 * * \\
(0.01)\end{array}$ & $\begin{array}{l}-22.60 \\
(0.12)\end{array}$ & \\
\hline M growth & $\begin{array}{c}0.12 * * \\
(0.00)\end{array}$ & $\begin{array}{l}0.12 * * \\
(0.00)\end{array}$ & $\begin{array}{c}0.06 * * \\
(0.00)\end{array}$ & $\begin{array}{l}0.06 * * \\
(0.00)\end{array}$ & $\begin{array}{c}0.09 * * \\
(0.00)\end{array}$ & $\begin{array}{l}0.09 * * \\
(0.00)\end{array}$ & $\begin{array}{l}0.11^{* *} \\
(0.00)\end{array}$ & $\begin{array}{c}0.11 * * \\
(0.00)\end{array}$ \\
\hline Wage & & & & & $\begin{array}{c}13.31 * * \\
(0.00)\end{array}$ & $\begin{array}{c}12.22 * * \\
(0.00)\end{array}$ & $\begin{array}{l}5.95 * * \\
(0.00)\end{array}$ & $\begin{array}{l}7.68 * * \\
(0.00)\end{array}$ \\
\hline IT Dummy & $\begin{array}{c}-6.86^{* *} \\
(0.00)\end{array}$ & $\begin{array}{c}-6.86^{* *} \\
(0.00)\end{array}$ & $\begin{array}{l}-0.47 \\
(0.70)\end{array}$ & $\begin{array}{l}-0.47 \\
(0.69)\end{array}$ & $\begin{array}{c}-6.37^{* *} \\
(0.00)\end{array}$ & $\begin{array}{c}-7.13 * * \\
(0.00)\end{array}$ & $\begin{array}{c}-9.91 * * \\
(0.00)\end{array}$ & $\begin{array}{c}-8.89^{* *} \\
(0.00)\end{array}$ \\
\hline R-squared & 0.64 & 0.65 & 0.85 & 0.86 & 0.74 & 0.75 & 0.69 & 0.70 \\
\hline
\end{tabular}

Note: Dependent variable is inflation. Panel data for regressions between (1) and (4) include a time period of 2000-2012 with 17 cross units. Regressions from (5) to (8) include 12 cross units after removing countries where real wage is unavailable. The panel regressions above have time and country effects. $\left({ }^{*}\right)$ and $\left({ }^{* *}\right)$ denote $10 \%$ and $5 \%$ significance level, successively. The test used is panel fixed effects.

Table 5. Dynamic Panel GMM estimates of the determinants of inflation for emerging economies (Non-IT and IT together)

\begin{tabular}{lcccc}
\hline Regressors: & $(1)$ & $(2)$ & $(3)$ & $(4)$ \\
\hline & & & & \\
Lagged inflation & $0.68^{* *}$ & $0.67^{* *}$ & $0.72^{* *}$ & $0.70^{* *}$ \\
Wage & $(0.03)$ & $(0.03)$ & $(0.03)$ & $(0.03)$ \\
& & & $4 \mathrm{e}-05$ & $2 \mathrm{e}-05$ \\
REER & & & $(6 \mathrm{e}-05)$ & $(6 \mathrm{e}-05)$ \\
& $-0.04^{* *}$ & $-0.04^{* *}$ & -0.003 & -0.001 \\
Output gap & $(0.02)$ & $(0.02)$ & $(0.006)$ & $(0.01)$ \\
& $11.09^{*}$ & & $10.21^{*}$ & \\
BB/GDP & $(5.71)$ & & $(6.04)$ & -0.02 \\
& -0.004 & 0.02 & 0.003 & $(0.06)$ \\
M growth & $(0.05)$ & $(0.05)$ & $(0.06)$ & $0.06^{* *}$ \\
& $0.06^{* *}$ & $0.07^{* *}$ & $0.06^{* *}$ & $(0.02)$ \\
Dummy & $(0.02)$ & $(0.02)$ & $(0.02)$ & 0.38 \\
& 0.05 & 0.01 & 0.45 & $(0.476)$ \\
GDP growth & $(0.40)$ & $(0.42)$ & $(0.46)$ & -3.57 \\
& & -0.04 & & $(5.84)$ \\
Constant & & $(0.06)$ & & \\
& $4.20^{* *}$ & $4.17^{* *}$ & & 144 \\
Observations & $(1.73)$ & $(1.82)$ & & 12 \\
No. of cross section & 204 & 204 & 144 & 0.542 \\
AR(2) & 17 & 17 & 12 & 0.579 \\
Sargan test & 0.427 & 0.469 & 0.964 & 0.565 \\
\hline
\end{tabular}

Note: Dependent variable is inflation. Standard errors are given in parentheses. $(*)$ and $(* *)$ denote $10 \%$ and $5 \%$ significance level, successively. The test used is Arellano and Bover (1995) system GMM test. 


\subsubsection{Empirical Findings for Industrialized Economies}

Similar to emerging market economies, lagged inflation is significant in all cases for industrialized economies and the coefficients are relatively higher in IT countries. Higher lagged inflation in EMEs compared to industrialized countries may be attributed to the fact that many developing countries historically and still have relatively high inflation rates which increases the inertia.

REER is negative and highly significant in Tables 6 and 7, however, the impact is relatively lower compared to emerging economies. If a rise in REER occurs through appreciation of the exchange rate, then relatively lower coefficients for industrialized countries will express lower exchange rate pass-through mechanism. Pass-through depends on some factors (Note 12) such as operating in imperfectly competitive market conditions, menu costs, pricing-to-market, staggering prices. It is observed that industrial countries reflect relatively lower coefficients compared to EMEs. The asymmetric impact of REER regarding EMEs and industrialized countries is consistent with the previous empirical study by Kamin (1997), who observed a higher responsiveness of inflation to REER in Latin America compared to Asian and industrialized countries. Such an asymmetric response may be attributed to the fact that EMEs have a higher dependency on foreign goods compared to industrialized countries. This is especially the case for relatively expensive technological products; hence the appreciation in the currency will bring about a higher decline in inflation in EMEs. Leiderman and Bufman (1996) also present evidence suggesting that the degree of pass-through from exchange rates to prices is higher in countries with high-inflation.

Differently from emerging economies, money growth is not significantly effective on industrialized countries. This can be attributed to the fact that currencies of industrialized economies are used as safe currencies (international reserve) such that inflation does not respond to the rise in money growth. Moreover, European economies have been undergoing slow or negative growth rates. Under such a low capacity production level, expansionary monetary policy may affect GDP growth rate rather than inflation together with the stimulation of the production facilities. One of the striking findings in this study is the sign difference of real minimum wage between emerging and industrialized countries. Emerging economies suggest positive coefficients for real wage, whereas it is negative for industrialized economies given in Tables from 6 to 9. The negative sign may be attributed to the following transmission mechanism. Industrialized economies offer very high real wages compared to emerging ones, as observed in Table 2. Industrialized economies go through high technology production utilizing high qualified labors contrary to emerging countries. Highly qualified labors in the production process not only keep real wages higher but also bring about competitiveness in the global arena. Rise in real wages specifies a rise in productivity. If the production cost does exceed the productivity increase, higher the productivity reduces inflation. Moreover, industrialized countries have higher saving rates and a rise in wages will not bring about a rise in their expenditure level as observed in emerging economies.

Dummy variable for IT is observed to be insignificant indicating that IT does not help lowering inflation rate in industrialized countries. Budget balance for industrialized economies reflect negative impact on inflation for IT countries under FE models, whereas the sign changes to positive for non-IT industrialized economies. Non-IT industrialized economies are (except for Finland, Japan, Switzerland) Eurozone countries plus the US. The Euro zone economies are rich in capital, eligible to reach funds and have monetary union which enable them to break the link from budget deficit to inflation. Other non-Eurozone economies plus the US economy are also rich in capital which enables them to circumvent the inflationary pressure. For instance, the US economy is known to have large budget deficits for many years. However, several questionable exogenous motives contribute to the budget finance in the form of government bond purchase. Demand for government bonds prevents seignorage effect, thus inflationary effect.

Table 6. Estimates of the determinants of inflation for non-IT industrialized economies

\begin{tabular}{ccccccccc}
\hline Regressors: & FE & FE & FE & FE & FE & FE & GMM & GMM \\
& $(1)$ & $(2)$ & $(3)$ & $(4)$ & $(5)$ & $(6)$ & $(1)$ & $(2)$ \\
\hline Lagged & $0.15^{* *}$ & $0.15^{*}$ & & & & & $0.35^{* *}$ & $0.43^{* *}$ \\
inflation & $(0.05)$ & $(0.06)$ & & & & & $(0.06)$ & $(0.07)$ \\
& & & & & $-\mathbf{0 . 0 5 * *}$ & $\mathbf{- 0 . 0 1}$ \\
REER & $\mathbf{- 0 . 0 5 * *}^{* *}$ & $\mathbf{- 0 . 0 5 * *}$ & $\mathbf{- 0 . 0 6 * *}$ & $\mathbf{- 0 . 0 6 * *}$ & & & $\mathbf{( 0 . 0 1 )}$ & $\mathbf{( 0 . 0 2 )}$
\end{tabular}




\begin{tabular}{|c|c|c|c|c|c|c|c|c|}
\hline Output gap & $\begin{array}{c}2.23 \\
(0.68)\end{array}$ & & $\begin{array}{c}2.20 \\
(0.67)\end{array}$ & & $\begin{array}{c}9.12 \\
(0.18)\end{array}$ & & $\begin{array}{c}16.71^{* *} \\
(4.44)\end{array}$ & \\
\hline BB/GDP & $\begin{array}{c}0.13^{* *} \\
(0.00)\end{array}$ & $\begin{array}{c}0.13^{* * *} \\
(0.00)\end{array}$ & $\begin{array}{c}0.14^{* *} \\
(0.00)\end{array}$ & $\begin{array}{c}0.15^{* *} \\
(0.00)\end{array}$ & $\begin{array}{c}0.15^{* * *} \\
(0.00)\end{array}$ & $\begin{array}{c}0.17 * * \\
(0.00)\end{array}$ & $\begin{array}{c}0.03 \\
(0.03)\end{array}$ & $\begin{array}{c}0.03 \\
(0.03)\end{array}$ \\
\hline $\begin{array}{l}\text { GDP } \\
\text { growth }\end{array}$ & & $\begin{array}{l}-0.02 \\
(0.77)\end{array}$ & & $\begin{array}{l}-0.04 \\
(0.52)\end{array}$ & & $\begin{array}{c}0.06 \\
(0.46)\end{array}$ & & $\begin{array}{c}0.23^{* *} \\
(0.04)\end{array}$ \\
\hline$M$ growth & $\begin{array}{c}-0.02 * \\
(0.08)\end{array}$ & $\begin{array}{l}-0.02 \\
(0.12)\end{array}$ & $\begin{array}{l}-0.02 \\
(0.13)\end{array}$ & $\begin{array}{l}-0.01 \\
(0.21)\end{array}$ & $\begin{array}{l}-0.02 \\
(0.13)\end{array}$ & $\begin{array}{l}-0.03^{*} \\
(0.10)\end{array}$ & $\begin{array}{l}-0.01 \\
(0.01)\end{array}$ & $\begin{array}{l}-0.02 \\
(0.02)\end{array}$ \\
\hline Wage & & & & & $\begin{array}{c}-4.42 * * \\
(0.00)\end{array}$ & $\begin{array}{c}-3.88 * * \\
(0.00)\end{array}$ & & \\
\hline Constant & & & & & & & $\begin{array}{c}5.90 * * \\
(1.41)\end{array}$ & $\begin{array}{c}1.76 \\
(1.56)\end{array}$ \\
\hline R-squared & 0.75 & 0.75 & 0.75 & 0.75 & 0.78 & 0.77 & $\begin{array}{c}\text { AR(2): } \\
\text { pval }=0.54 \\
\text { Sargan } \\
\text { test: } \\
\text { pval }=0.17\end{array}$ & $\begin{array}{c}\text { AR(2): } \\
\text { pval }=0.33 \\
\text { Sargan } \\
\text { test: } \\
\text { pval }=0.51\end{array}$ \\
\hline
\end{tabular}

Note: Dependent variable is inflation. p-values are given in parenthesis. Dependent variable is CPI inflation rate. Panel data for regressions between (1) and (4) include a time period of 2001-2012 with 16 cross units. Regressions (5) and (6) include 10 cross units after removing countries (Austria, Denmark, Finland, Germany, Ireland and Switzerland) where real wage is unavailable. The panel regressions above have time and country effects. $(*)$ and $(* *)$ denote $10 \%$ and $5 \%$ significance level, successively. GMM tests are applied to $\mathrm{N}=16$ dataset, i.e., without wage. For GMM, standard deviations are given in parentheses. FE denotes panel fixed effect whereas GMM denotes Arellano and Bover (1995) system GMM.

Table 7. Estimates of the determinants of inflation for IT industrialized economies

\begin{tabular}{|c|c|c|c|c|c|c|}
\hline Regressors: & (1) & (2) & (3) & (4) & (5) & (6) \\
\hline Lagged inflation & & & $\begin{array}{l}0.23 * * \\
(0.02)\end{array}$ & $\begin{array}{l}0.34 * * \\
(0.04)\end{array}$ & & \\
\hline REER & $\begin{array}{c}-0.06 * * \\
(0.00)\end{array}$ & $\begin{array}{l}-0.03 * \\
(0.07)\end{array}$ & $\begin{array}{c}-0.05 * * \\
(0.00)\end{array}$ & $\begin{array}{l}-0.03 * \\
(0.09)\end{array}$ & & \\
\hline Output gap & $\begin{array}{c}47.20^{* *} \\
(0.00)\end{array}$ & & $\begin{array}{c}46.69^{* *} \\
(0.00)\end{array}$ & & $\begin{array}{l}14.81^{*} \\
(0.09)\end{array}$ & \\
\hline BB/GDP & $\begin{array}{c}-0.16 * * \\
(0.00)\end{array}$ & $\begin{array}{c}-0.16 * * \\
(0.01)\end{array}$ & $\begin{array}{c}-0.13 * * \\
(0.00)\end{array}$ & $\begin{array}{c}-0.14 * * \\
(0.03)\end{array}$ & $\begin{array}{c}-0.14 * * \\
(0.04)\end{array}$ & $\begin{array}{l}-0.11 * \\
(0.09)\end{array}$ \\
\hline GDP growth & & $\begin{array}{l}-0.06 \\
(0.54)\end{array}$ & & $\begin{array}{c}0.09 \\
(0.45)\end{array}$ & & $\begin{array}{l}-0.14^{*} \\
(0.06)\end{array}$ \\
\hline $\mathrm{M}$ growth & $\begin{array}{l}-0.004 \\
(0.79)\end{array}$ & $\begin{array}{c}0.01 \\
(0.48)\end{array}$ & $\begin{array}{c}0.01 \\
(0.64)\end{array}$ & $\begin{array}{c}0.02 \\
(0.23)\end{array}$ & & \\
\hline Wage & & & & & $\begin{array}{c}-4.47 * * \\
(0.00)\end{array}$ & $\begin{array}{c}-3.69^{* *} \\
(0.00)\end{array}$ \\
\hline R-squared & 0.84 & 0.72 & 0.84 & 0.73 & 0.79 & 0.80 \\
\hline
\end{tabular}

Note: p-values are given in parenthesis. Dependent variable is CPI inflation rate. Panel data for regressions between (1) and (4) include a time period of 2001-2012 with 7 cross units. Regressions (5) and (6) include 4 cross units after removing countries (Iceland, Norway and Sweden) where real wage is unavailable. The panel regressions above have time and country effects. $\left({ }^{*}\right)$ and $\left({ }^{*}\right)$ denote $10 \%$ and $5 \%$ significance level, successively. The test used is panel fixed effects. 
Table 8. Estimates of the determinants of inflation for industrialized economies (Non-IT and IT together)

\begin{tabular}{|c|c|c|c|c|c|c|}
\hline Regressors: & (1) & (2) & (3) & (4) & (5) & (6) \\
\hline Lagged inflation & $\begin{array}{c}0.65 * * \\
(0.00)\end{array}$ & $\begin{array}{c}0.65 * * \\
(0.00)\end{array}$ & $\begin{array}{c}0.51 * * \\
(0.00)\end{array}$ & $\begin{array}{c}0.51 * * \\
(0.00)\end{array}$ & $\begin{array}{l}0.51 * * \\
(0.00)\end{array}$ & \\
\hline REER & $\begin{array}{c}-0.01 \\
(0.17)\end{array}$ & $\begin{array}{r}-0.003 \\
(0.65)\end{array}$ & $\begin{array}{l}-0.01 \\
(0.40)\end{array}$ & $\begin{array}{l}-0.01 \\
(0.59)\end{array}$ & & $\begin{array}{c}-0.02 * * \\
(0.04)\end{array}$ \\
\hline Output gap & $\begin{array}{c}17.70 * * \\
(0.00)\end{array}$ & & $\begin{array}{c}1.50 \\
(0.80)\end{array}$ & & & \\
\hline BB/GDP & $\begin{array}{c}-0.04 * * \\
(0.02)\end{array}$ & $\begin{array}{l}-0.03 * \\
(0.06)\end{array}$ & $\begin{array}{l}0.05^{*} \\
(0.09)\end{array}$ & $\begin{array}{l}0.05 * \\
(0.09)\end{array}$ & $\begin{array}{c}0.06 * * \\
(0.03)\end{array}$ & $\begin{array}{c}0.08 * * \\
(0.01)\end{array}$ \\
\hline GDP growth & & $\begin{array}{l}0.07 * \\
(0.10)\end{array}$ & & $\begin{array}{c}0.08 \\
(0.16)\end{array}$ & & $\begin{array}{c}0.10 \\
(0.11)\end{array}$ \\
\hline M growth & $\begin{array}{l}0.02 * \\
(0.06)\end{array}$ & $\begin{array}{c}0.02 * * \\
(0.04)\end{array}$ & $\begin{array}{c}-0.004 \\
(0.73)\end{array}$ & $\begin{array}{l}-0.01 \\
(0.48)\end{array}$ & & $\begin{array}{c}0.02 \\
(0.17)\end{array}$ \\
\hline Wage & & & $\begin{array}{c}-0.39 * * \\
(0.05)\end{array}$ & $\begin{array}{l}-0.35^{*} \\
(0.07)\end{array}$ & $\begin{array}{c}-0.45 * * \\
(0.01)\end{array}$ & $\begin{array}{c}-0.82 * * \\
(0.00)\end{array}$ \\
\hline Dummy & $\begin{array}{l}0.31 * \\
(0.06)\end{array}$ & $\begin{array}{c}0.22 \\
(0.18)\end{array}$ & $\begin{array}{c}0.14 \\
(0.45)\end{array}$ & $\begin{array}{c}0.11 \\
(0.55)\end{array}$ & $\begin{array}{c}0.15 \\
(0.43)\end{array}$ & $\begin{array}{c}0.12 \\
(0.56)\end{array}$ \\
\hline R-squared & 0.62 & 0.60 & 0.63 & 0.63 & 0.62 & 0.48 \\
\hline
\end{tabular}

Note: p-values are given in parenthesis. Dependent variable is CPI inflation rate. Panel data for regressions between (1) and (2) include a time period of 2001-2012 with 23 cross units. Regressions from (3) to (6) include 14 cross units after removing countries where real wage is unavailable. The panel regressions above have time effects. $(*)$ and $(* *)$ denote $10 \%$ and $5 \%$ significance level, successively. The test used is panel fixed effects.

Table 9. Dynamic Panel GMM estimates of the determinants of inflation for industrialized economies (Non-IT and IT together)

\begin{tabular}{lcccc}
\hline Regressors: & $(1)$ & $(2)$ & $(3)$ & $(4)$ \\
\hline Lagged inflation & & & & \\
& $0.305^{* *}$ & $0.357^{* *}$ & $0.305^{* *}$ & $0.335^{* *}$ \\
Wage & $(0.0719)$ & $(0.0721)$ & $(0.0730)$ & $(0.0713)$ \\
& & & $-2.86 \mathrm{e}-05^{*}$ & $-1.30 \mathrm{e}-05$ \\
REER & & & $(1.58 \mathrm{e}-05)$ & $(1.59 \mathrm{e}-05)$ \\
& $-0.0247^{* *}$ & -0.00563 & & \\
Output gap & $(0.018)$ & $(0.0118)$ & & \\
& $11.07^{* *}$ & & 7.752 & \\
BB/GDP & $(5.507)$ & & $(5.412)$ & 0.0323 \\
& 0.0478 & 0.0368 & $0.0740^{* *}$ & $(0.0288)$ \\
M growth & $(0.0323)$ & $(0.0290)$ & $(0.0318)$ & \\
& -0.00430 & -0.0193 & -0.00932 & 0.0455 \\
Dummy & $(0.0156)$ & $(0.0158)$ & $(0.0156)$ & $(0.241)$ \\
& 0.0758 & 0.0163 & 0.132 & $0.199^{* *}$ \\
GDP growth & $(0.241)$ & $(0.236)$ & $(0.247)$ & $(0.0470)$ \\
& & $0.219 * *$ & & $1.446^{* *}$ \\
Constant & & $(0.0485)$ & & 1547 \\
\hline Observations & 1.838 & $2.324^{* *}$ & 14 \\
No. of cross section & $2.144^{* *}$ & $(1.235)$ & $(0.437)$ & 0.178 \\
AR(2) & 23 & 253 & 154 & 0.449 \\
Sargan test & 0.398 & 23 & 14 & \\
\hline
\end{tabular}

Note: Same notes as in Table 5. 


\section{Conclusion}

In this study the determinants of inflation rate is investigated for a panel of 40 economies considering the distinction of inflation targeting and non-inflation targeting for emerging and industrial economies for the relatively lower global inflation period (after 2001). The variables to investigate as the determinants of inflation are selected taking into account of the empirical literature. These variables are real effective exchange rate, output gap, budget balance as a ratio of GDP, GDP growth, money growth and real minimum wage. Since some of these variables may have dependency among each other, several regression combinations are constructed.

Real effective exchange rate reflects a negative impact on inflation. The coefficient for emerging market economies are higher compared to industrialized economies which is mainly consistent with the similar studies. Edwards (2006, p.3) states that "historically, pass-through has tended to be large in emerging countries and, in particular, in countries that experience a currency crises". Money growth rate is observed to contribute to inflation in emerging economies whereas the impact is insignificant for industrialized countries. Demand for currencies of industrialized economies prevents the link from money growth to inflation. Real wage has a positive impact in emerging economies, whereas the impact is negative for industrialized economies. Different production characteristics may provide an explanation for this difference. Budget balance for emerging economies and IT industrialized economies reflect a negative effect on inflation. However, the sign is reverse for non-IT industrialized economies which may be attributed to the special conditions of these economies, such as abundance in capital and/or the ability to find funds via being a member of a monetary union.

The study also tests the impact of inflation targeting. The response of inflation is observed to be negative in emerging economies. However, some studies argue that there may be illusion if the lagged inflation is absent in the regression model. Taking into account of this sensitivity, the model is tested together with the division of IT and non-IT countries. Hence, the impact of IT for EMEs is ambiguous. The study generally reflects diverse results in the investigation of determinants of inflation. The empirical findings suggest that central banks of emerging market economies should not replicate the monetary policies employed by industrialized economies due to different mechanisms.

\section{References}

Arellano, M., \& Bond, S. (1991). Some tests of specification for panel data: Monte Carlo evidence and an application to employment equations. Review of Economic Studies, 58, 277-297. http://dx.doi.org/10.2307/2297968

Arellano, M., \& Bover, O. (1995). Another look at the instrumental variable estimation of error-components models. Journal of Econometrics, 68, 29-51. http://dx.doi.org/10.1016/0304-4076(94)01642-D

Ball, L. (1999). Policy rules for open economies. In John B. Taylor (Ed.), Monetary Policy Rules (pp. 127-156). Chicago: University of Chicago Press.

Ball, L., \& Sheridan, N. (2005). Does Inflation Targeting Matter?. In Ben S. Bernanke and Michael Woodford (Eds.), The Inflation Targeting Debate. NBER Studies in Business Cycles (Vol. 32). Chicago: University of Chicago Press.

Benati, L. (2008). Investigating Inflation Persistence across Monetary Regimes. ECB working paper, No. 851. Retrieved from www.ecb.europa.eu/pub/pdf/scpwps/ecbwp851.pdf

Brito, R. D., \& Bystedt, B. (2010). Inflation targeting in emerging economies: Panel evidence. Journal of Development Economics, 91(2), 198-210. http://dx.doi.org/10.1016/j.jdeveco.2009.09.010

Ca'Zorzi, M., Hahn, E., \& Sánchez, M. (2007). Exchange rate pass-through in emerging markets. European Central Bank Working Paper 739. Retrieved from https://www.ecb.europa.eu/pub/pdf/scpwps/ecbwp739.pdf

Catao, L. A., \& Terrones, M. E. (2005). Fiscal deficits and inflation. Journal of Monetary Economics, 52(3), 529-554. http://dx.doi.org/10.1016/j.jmoneco.2004.06.003

Cecchetti, S. G., \& Ehrmann, M. (1999). Does Inflation Targeting Increase Output Volatility? An International Comparison of Policymakers' Preferences and Outcomes. NBER Working Paper 7426.

Cheng, H. L., \& Papi, L. (1997). An econometric analysis of the determinants of inflation in Turkey. International Monetary Fund, IMF Working Paper No. 97/170.

Choudhri, E. U., \& Hakura, D. S. (2006). Exchange rate pass-through to domestic prices: does the inflationary environment matter?. Journal of International Money and Finance, 25(4), 614-639. http://dx.doi.org/10.1016/j.jimonfin.2005.11.009 
Christiano, L., Eichenbaum, M., \& Charles Evans. (2005). Nominal Rigidities and the Dynamic Effects of a Shock to Monetary Policy. Journal of Political Economy, 113(1), 1-45. http://dx.doi.org/10.1086/426038

Durevall, D. (1999). Inertial Inflation, Price Stickiness and Indexation: Evidence from Brazil. Journal of Development Economics, 60(2), 407-421.

Égert, B., I. Drine, K. Lommatzsch, \& Ch. Rault. (2003). The Balassa-Samuelson Effect in Central and Eastern Europe: Myth or Reality?. Journal of Comparative Economics, 31(3), 552-572. http://dx.doi.org/10.1016/S0147-5967(03)00051-9

Fischer, S., Sahay, R., \& Ve'gh, C. (2002). Modern hyper-and high inflations. Journal of Economic Literature, 40, 837-880.

Frankel, J., Parsley, D., \& Wei, S. J. (2005). Slow Pass-Through around the World: A New Import for Developing Countries?. NBER Working Paper No. 11199.

Friedman, M. (1956). The Quantity Theory of Money: A Restatement. In M. Friedman (Ed.), Studies in the Quantity Theory of Money (pp. 3-21). Chicago: University of Chicago Press.

Grauwe, P. D., \& Polan, M. (2005). Is inflation always and everywhere a monetary phenomenon?. Scandinavian Journal of Economics, 107, 239-259. http://dx.doi.org/10.1111/j.1467-9442.2005.00406.x

Jahan, S. (2012). Inflation Targeting: Holding the Line. Finance \& Development. Retrieved from http://www.imf.org/external/pubs/ft/fandd/basics/target.htm

Johnson, D. R. (2002). The effect of inflation targeting on the behavior of expected inflation: evidence from an 11 country panel. Journal of Monetary Economics, 49(8), 1521-38. http://dx.doi.org/10.1016/S0304-3932(02)00181-2

Kamin, S. B. (1997). A Multi-Country Comparison of the Linkages between Inflation and Exchange Rate Competitiveness. Bank for International Settlements, Working Papers, No.45.

Karras, G. (1994). Government spending and private consumption: some international evidence. Journal of Money, Credit and Banking, 26(1), 9-22. http://dx.doi.org/10.2307/2078031

King, R., \& Plosser, C. (1985). Money, deficits, and inflation. Carnegie Rochester Conference Series on Public Policy, 22, 147-196. http://dx.doi.org/10.1016/0167-2231(85)90031-4

Klau, M. (1998). Exchange rate regimes and inflation and output in Sub-Saharan Countries. BIS Working Papers No. 53.

Komulainen, T., \& Pirttila, J. (2002). Fiscal explanations for inflation: Any evidence from transition economies?. Economic Planning, 35, 293-316. http://dx.doi.org/10.1023/A:1022491613255

Leitemo, K., Roisland, O., \& Torvik, R. (2002). Time inconsistency and the exchange rate channel of monetary policy. Scandinavian Journal of Economics, 104(3), 391-397. http://dx.doi.org/10.1111/1467-9442.00293

Levin, A. T., Natalucci, F. M., \& Piger, J. M. (2004). The Macroeconomic Effects of Inflation Targeting. Federal Reserve Bank of St. Louis Review, 86(4), 51-80.

Lin, Hsin-Yi, \& Chu, Hao-Pang. (2013). Are fiscal deficits inflationary?. Journal of International Money and Finance, 32, 214-233. http://dx.doi.org/10.1016/j.jimonfin.2012.04.006

Lin, S., \& Ye, H. (2009). Does inflation targeting make a difference in developing countries?. Journal of Development Economics, 89(1), 118-123. http://dx.doi.org/10.1016/j.jdeveco.2008.04.006

Lucas, Jr, R. E. (1976). Econometric policy evaluation: A critique. Carnegie-Rochester conference series on public policy, 1, 19-46. http://dx.doi.org/10.1016/S0167-2231(76)80003-6

Masso, J., \& Staehr, K. (2005). Inflation dynamics and nominal adjustment in the Baltic States. Research in International Business and Finance, 19, 281-303. http://dx.doi.org/10.1016/j.ribaf.2004.12.006

Mihaljek, D., \& Klau, M. (2008). Exchange rate pass-through in emerging market economies: what has changed and why?". In Transmission mechanisms for monetary policy in emerging market economies, BIS Papers, No 35, January.

Mishkin, F. S., \& Schmidt-Hebbel, K. (2007). Does Inflation Targeting Make a Difference?. NBER Working Paper No. 12876. Retrieved from http://www.nber.org/papers/w12876

Neumann, M. J. M., \& von Hagen, J. (2002). Does Inflation Targeting Matter?. Review (Federal Reserve Bank of St. Louis), 84(4), 127-48. 
Neyapti, B. (2003). Budget deficits and inflation: the roles of central bank independence and financial market development. Contemporary Economic Policy, 21(4), 458-475. http://dx.doi.org/10.1093/cep/byg025

Roodman, D. (2009). How to do xtabond2: An introduction to difference and system GMM in Stata. The Stata Journal, 9(1), 86-136.

Sargent, T. J., \& Wallace, N. (1981). Some Unpleasant Monetarist Arithmetic. Federal Reserve Bank of Minneapolis Quarterly Review, 9(1), 15-31.

Svensson, L. (1997). Inflation forecast targeting: Implementing and monitoring inflation targets. European Economic Review, 41, 1111-46. http://dx.doi.org/10.1016/S0014-2921(96)00055-4

Svensson, L. (2000). Open-economy inflation targeting. Journal of International Economics, 50(1), 155-183. http://dx.doi.org/10.1016/S0022-1996(98)00078-6

Truman, E. M. (2003). Inflation Targeting in the World Economy. Washington, DC: Institute for International Economics.

Willard, L. B. (2012). Does inflation targeting matter? A reassessment. Applied Economics, 44, 2231-2244. http://dx.doi.org/10.1080/00036846.2011.564136

\section{Notes}

Note 1. Following 1997-1998 Asia-Russia crisis and 2001 crisis in Argentina and Turkey.

Note 2. Mishkin $(2004$, p. 1) explains what an inflation targeting regime means in five elements: "i) the public announcement of medium-term numerical targets for inflation; ii) an institutional commitment to price stability as the primary goal of monetary policy, to which other goals are subordinated; iii) an information inclusive strategy in which many variables, and not just monetary aggregates or the exchange rate, are used for deciding the setting of policy instruments; iv) increased transparency of the monetary policy strategy through communication with the public and the markets about the plans, objectives, and decisions of the monetary authorities; and v) increased accountability of the central bank for attaining its inflation objectives.

Note 3. In this study, we used an inverse definition for real exchange rate.

Note 4. These economies utilized fixed exchange rate regime.

Note 5. Canadian M2 growth rate data is obtained from Statistics Canada (CANSIM), New Zealand from Reserve Bank of New Zealand and Norway from Norges Bank.

Note 6. Brazilian (general government) budget balance as a ratio of GDP data is from Banco Central do Brasil, Chile from DIPRES-Chile, Indonesia from Statistics Indonesia, Israel from Bank of Israel (BOI), Mexico from Secretaria de Hacienda y Credito Publico treasury, Turkey from Turkish Treasury, Greece from Eurostat, India from Ministry of Finance of Government of India and Russia from Ministry of Finance of Russia.

Note 7. Estonian, Slovenian, Brazilian and Turkish REER are from Eurostat and India from Reserve Bank of India.

Note 8. Chinese real minimum wage in US dollars is from Statistics of China.

Note 9. The null hypothesis of Sargan test is instruments are not correlated with the residual.

Note 10. The null hypothesis of $\operatorname{AR}(2)$ test is "error terms in the differenced equation does not reflect serial correlation in the second order".

Note 11. REER $=\prod_{i=1}^{N}\left[\frac{P}{P_{i}^{*} e_{i}}\right]^{w_{i}}$ where $P$ is domestic price level; $P_{i}^{*}$ is price level in country $i ; e_{i}$ is nominal exchange rate; and $w_{i}$ is country $i$ 's weight in domestic country's REER index. A rise in REER implies appreciation in the domestic currency.

Note 12. Dornbusch (1987) explains imperfectly competitive market conditions as a reason for incomplete pass-through; menu costs is a new Keynesian explanation; Taylor (1980)'s prominent staggering prices is another explanation. Krugman (1987) mentions about pricing-to-market where foreign producers make their mark-up adjustments taking into account of competitive market conditions. 